American J. of Engineering and Applied Sciences 2 (1):154-159, 2009

ISSN 1941-7020

(C) 2009 Science Publications

\title{
Effect of Diesel Engine Converted to Sequential Port Injection Compressed Natural Gas Engine on the Cylinder Pressure vs Crank Angle in Variation Engine Speeds
}

\author{
${ }^{1}$ Semin, ${ }^{2}$ Abdul Rahim Ismail and ${ }^{2}$ Rosli Abu Bakar \\ ${ }^{1}$ Department of Marine Engineering, Institute of Technology Sepuluh Nopember Surabaya, Indonesia \\ ${ }^{2}$ Faculty of Mechanical Engineering, University Malaysia Pahang, Malaysia
}

\begin{abstract}
The diesel engine converted to compressed natural gas (CNG) engine effect is lower in performance. Problem statement: The hypothesis is that the lower performance of CNG engine is caused by the effect of lower in engine cylinder pressure. Are the CNG engine is lower cylinder pressure than diesel engine? This research is conducted to investigate the cylinder pressure of CNG engine as a new engine compared to diesel engine as a baseline engine. Approach: The research approach in this study is by convert the diesel engine to multi point injection dedicated CNG engine. The engine conversion is by changed the diesel fuel to CNG fuel, changed the injection fuel system, changed the ignition system, modified piston to reduce the compression ratio and added throttle to in intake port. If the development is completed, the engine cylinder pressure is investigated. In this study, the cylinder pressure is investigated in 7 cases engine speed from 1000 to $4000 \mathrm{rpm}$ with range in 500 . Results: The research results are cylinder pressure and maximum pressure of $\mathrm{CNG}$ engine compared to diesel engine in 1000 to $4000 \mathrm{rpm}$ engine speed. Conclusion/Recommendations: Effect of diesel engine converted to $\mathrm{CNG}$ engine is decrease the cylinder pressure. The further research is needed to find the higher performance of $\mathrm{CNG}$ engine.
\end{abstract}

Key words: CNG engine conversion effect, cylinder pressure, engine speed effect

\section{INTRODUCTION}

The CNG engine is lower performance compare to diesel. The range for CNG engine is typically limited to about $40 \%-50 \%$ of gasoline fueled engine ${ }^{[1]}$. Several factors affecting the low engine power and torque according to Bysveen ${ }^{[2]}$ are loses in volumetric efficiency, low flame speed, low compression ratio, absence of fuel evaporation and change in stoichimetric air/fuel ratio.

In the losses in volumetric efficiency, the power loss could be partly explained by the low density of natural gas ${ }^{[2]}$. The natural gas in the mixture drawn into the cylinder displaces approximately $8-10 \%$ of oxygen available for combustion. In other words, CNG in its gaseous state, decreases volumetric efficiency by the same amount and consequently reducing performance.

For the flame speed, natural gas has a very low flame speed, which is much lower than gasoline. Values as much as $60 \%$ decrease in lower burning velocity for natural gas has been measured ${ }^{[3]}$. This effect on the total combustion duration is prolonged compared with diesel and gasoline. With the conventional valve timing setting for liquid fuel engines, it would be impossible for CNG operation to complete the whole combustion before the exhaust valve opens, even if the gas mixture was ignited earlier. This can cause a further reduction in the engine output of 5-10\%.

For the Compression Ratio (CR), current gas engine practice mainly limited to simple conversion from either gasoline or diesel engines. For SI engines, the $\mathrm{CR}$ is in the range of 8:1-9.5:1. On the other hand, the CNG with higher octane rating allows engine CR increase up to $15: 1$. Increasing the CR would partially increase ideal efficiency and the power output ${ }^{[2]}$. Ganesan $^{[4]}$ states that for the important compression ratio range of 9-11 the relative efficiency improvement is between 1-3\% per unit compression ratio increase, depending on cylinder size and operating conditions.

Absence of fuel evaporation of CNG engine is when gasoline evaporates (required before combustion), the energy required for the phase change decrease intake charge temperature and air partial pressure ${ }^{[4,5]}$. The decrease in temperature offsets the decrease in air partial pressure and results in a positive increase to volumetric efficiency of about $2 \%$. CNG does not evaporate before combustion, losing any potential gain from the heat vaporization.

Corresponding Author: Semin, Department of Marine Engineering, Institute of Technology Sepuluh Nopember (ITS) Surabaya Campus ITS, Sukolilo, Surabaya 60111, Indonesia 
The stoichiometric air/fuel ratio for gasoline is about 14.6 while CNG is about 16.9 (methane is 17.2), indicating less $\mathrm{CNG}$ is required for a given air charge. Furthermore, CNG has a greater Lower Heating Value (LHV) indicating more available energy for each unit of mass. LHV value of CNG is around $46,736 \mathrm{~kJ} \mathrm{~kg}^{-1}$ while the LHV for gasoline approximately 43,961 kJ $\mathrm{kg}^{-1[2]}$. The octane rating of natural gas is about 130 , meaning that engines could operate at compression ration of up to $16: 1$ without knock or detonation ${ }^{[5]}$. Most importantly, natural gas significantly reduces $\mathrm{CO}_{2}$ emissions by $20-25 \%$ compare to gasoline because simple chemical structures of natural gas (primarily methane- $\mathrm{CH}_{4}$ ) contain one Carbon compare to diesel $\left(\mathrm{C}_{15} \mathrm{H}_{32}\right)$ and gasoline $\left(\mathrm{C}_{8} \mathrm{H}_{18}\right)^{[4-6]}$.

This study is focused on the engine conversion effect on the cylinder pressure versus crank angle in variation engine speed. So, in this research the characterization of cylinder pressure performance is pressure versus crank angle. Speed mode is the most commonly used mode of engine investigation ${ }^{[7-9]}$. According to ${ }^{[4,5]}$ the cylinder pressure is defined by the Eq. 1 and 2:

$$
\begin{aligned}
& \mathrm{P}=\mathrm{P}_{\max }\left(\frac{\mathrm{V}_{\mathrm{TDC}}}{\mathrm{V}}\right)^{\mathrm{m}} \\
& \mathrm{P}_{\max }=\mathrm{P}_{\mathrm{IVC}} \mathrm{R}_{\mathrm{c}}^{\gamma}+\mathrm{P}_{\text {comb }}
\end{aligned}
$$

Where:

$$
\begin{aligned}
\mathrm{P}= & \text { Instantaneous cylinder pressure between Top } \\
& \text { Dead Center (TDC) and the transition point } \\
\mathrm{P}_{\max }= & \text { Maximum cylinder pressure or pressure at } \\
& \text { TDC } \\
\mathrm{V}_{\mathrm{TDC}}= & \text { Cylinder volume at TDC } \\
\mathrm{V}= & \text { Instantaneous cylinder volume between TDC } \\
& \text { and the transition point } \\
\mathrm{m}= & \text { Slope of P-V curve after TDC } \\
\mathrm{P}_{\mathrm{IVC}}= & \text { Cylinder pressure at IVC } \\
\mathrm{R}_{\mathrm{c}}= & \text { Cylinder compression ratio } \\
\gamma & =\text { Specific heat ratio } \\
\mathrm{P}_{\text {comb }}= & \text { Pressure rise due to combustion }
\end{aligned}
$$

\section{MATERIALS AND METHODS}

This research activity is conducted to studies the diesel engine converted to multi point injection (sequential) dedicated Compressed Natural Gas (CNG) engine spark ignition. The baseline engine is a single cylinder four stroke direct injection diesel engine. The new engine is multi point injection (sequential) dedicated CNG engine spark ignition. The conversion and cylinder pressure performance investigation of the baseline diesel engine and multi point injection (sequential) dedicated CNG engine spark ignition are conducted at Automotive Laboratory, Faculty of Mechanical Engineering, University Malaysia Pahang, Malaysia. The conversion data is shown in Table 1.

The new design and development in this engine research activities are the direct injection diesel fuel system changed to multi point injection (sequential) CNG system, reduce compression ration, compression ignition converted to spark ignition, mechanical fuel control system changed to electronic fuel control system. So, in the CNG injection fuelling system, the sequential port injection of compressed natural gas fuel injector nozzle is changed to $\mathrm{CNG}$ injector. The basic fuelling system management of four stroke direct injection diesel engine is using mechanical fuelling pump system and fuel injected directly to the engine cylinder. In this research, the fuelling system management of the engine will be changed to electronic control fuelling system management for CNG fuelling system and the gas fuel is injected sequentially via intake port before intake valve. The illustration of engine conversion is shown in Fig. 1 and 2.

Table 1: The engine conversion specification data

\begin{tabular}{lcc}
\hline Engine and intake parameter & Diesel engine & CNG engine \\
\hline Bore (mm) & 86.00 & 86.0 \\
Stroke (mm) & 70.00 & 70.0 \\
Displacement (cc) & 407.00 & 407.0 \\
Compression ratio & 20.28 & 14.5 \\
Intake valve close (CA) & 496.00 & 496.0 \\
Exhaust valve open (CA) & 191.00 & 191.0 \\
Intake valve open (CA) & 361.00 & 361.0 \\
Exhaust valve close (CA) & 325.00 & 325.0 \\
Ignition system & Compression & Spark \\
Fuel injection system & Direct & Sequential \\
Fuel & Diesel & Natural gas \\
Intake port diameter in (mm) & 40.69 & 40.69 \\
Intake port diameter out (mm) & 32.78 & 32.78 \\
Intake port length (mm) & 55.20 & 55.20 \\
\hline
\end{tabular}

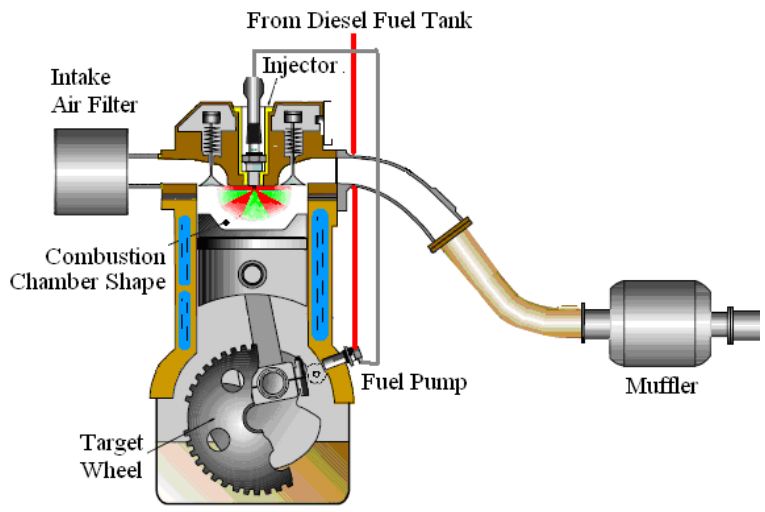

Fig. 1: Detail schematic of diesel engine 


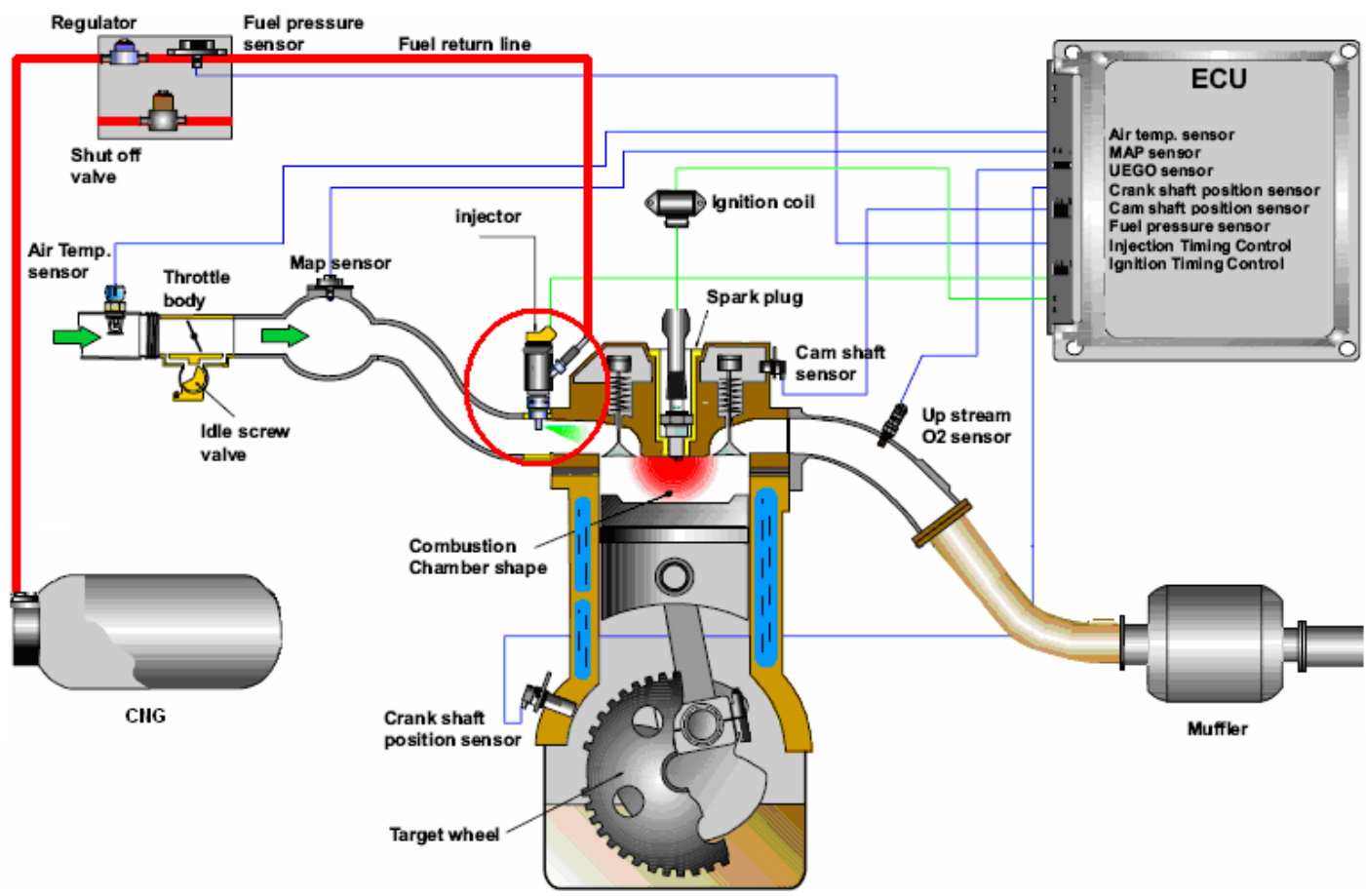

Fig. 2: Detail schematic of sequential CNG engine

The investigation that compute fastest should be run first generally, which means that case 1 should be the lowest engine speed typically and last case should be the highest engine speed. This will not effect plotting of output variable. The engine speed case setup both of diesel engine and CNG engine are in 1000, 1500, 2000, 2500, 3000, 3500 and $4000 \mathrm{rpm}$ engine speed.

\section{RESULTS}

The investigations of the engines are running in 7 cases based on engine speed. The engine is running at $1000-4000 \mathrm{rpm}$ with variation in $500 \mathrm{rpm}$. The results of the cylinder pressure performance effect of the engine conversion are shown in Fig. 3-10. Figure 3 shows the diesel engine converted to $\mathrm{CNG}$ engine effect in cylinder pressure versus crank angle at $1000 \mathrm{rpm}$ engine speeds. Fig. 4 shows the diesel engine converted to $\mathrm{CNG}$ engine effect in cylinder pressure versus crank angle profile on $1500 \mathrm{rpm}$ engine speeds. Fig. 5 shows the diesel engine converted to CNG engine effect in cylinder pressure versus crank angle at $2000 \mathrm{rpm}$ engine speeds. Fig. 6 shows the diesel engine converted to $\mathrm{CNG}$ engine effect in cylinder pressure versus crank angle at $2500 \mathrm{rpm}$ engine speeds. Fig. 7 shows the diesel engine converted to $\mathrm{CNG}$ engine effect in cylinder pressure versus crank angle at $3000 \mathrm{rpm}$ engine speeds. Fig. 8 shows the diesel engine converted to CNG engine effect in cylinder pressure versus crank angle profile at $3500 \mathrm{rpm}$ engine speeds. Fig. 9 shows the diesel engine converted to CNG engine effect in cylinder pressure versus crank angle profile at 4000 rpm engine speeds. Fig. 10 shows the diesel engine converted to CNG engine effect in cylinder maximum pressure versus engine speed profile at 1000-4000 rpm engine speeds.

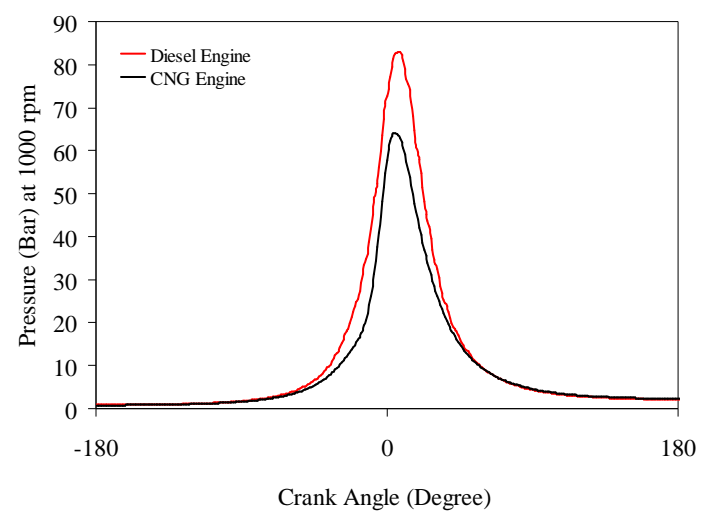

Fig. 3: Cylinder pressure at $1000 \mathrm{rpm}$ engine 
Am. J. Engg. \& Applied Sci., 2 (1):154-159, 2009

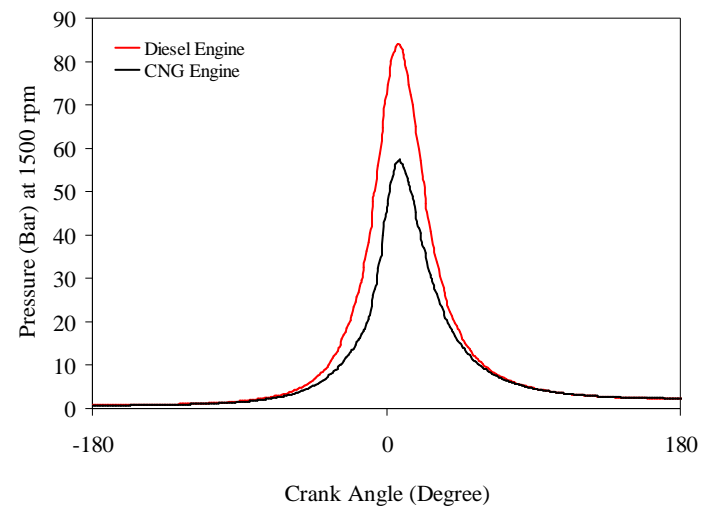

Fig. 4: Cylinder pressure at $1500 \mathrm{rpm}$ engine

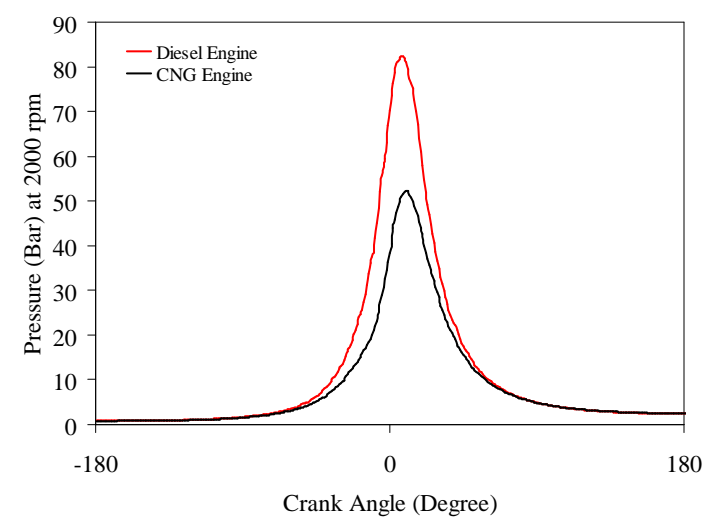

Fig. 5: Cylinder pressure at $200 \mathrm{rpm}$ engine

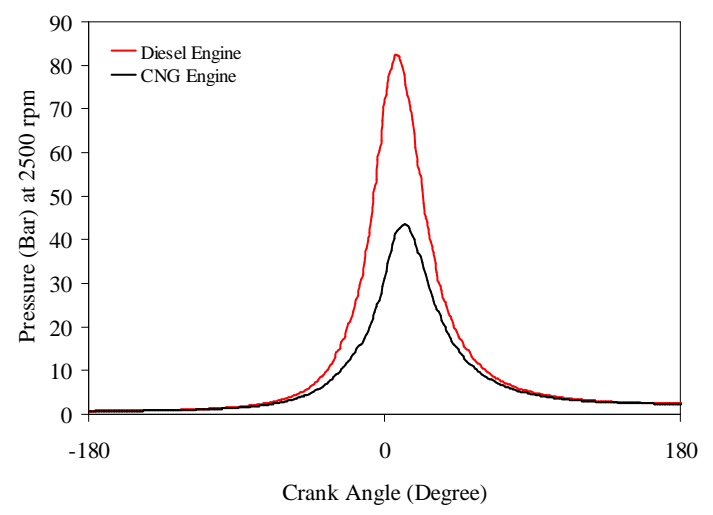

Fig. 6: Cylinder pressure at $2500 \mathrm{rpm}$ engine

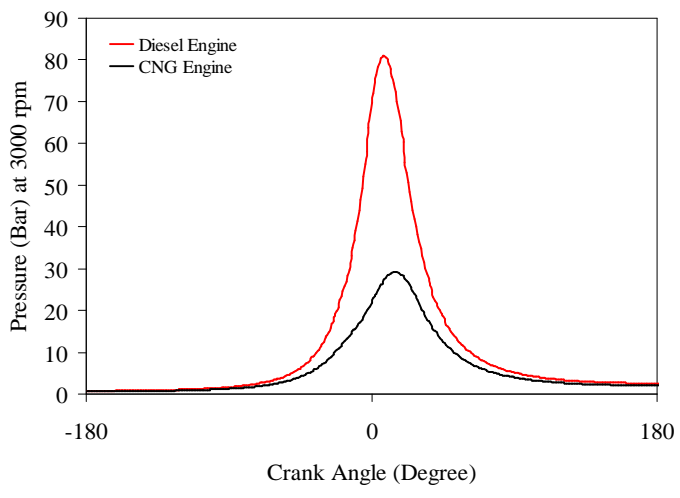

Fig. 7: Cylinder pressure at $3000 \mathrm{rpm}$ engine

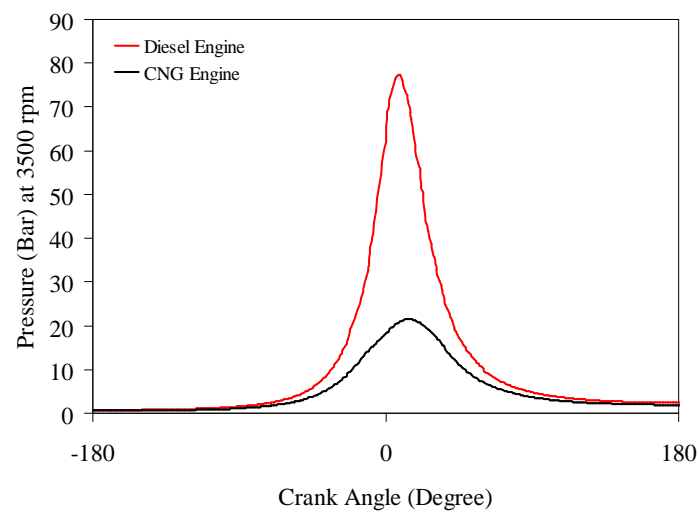

Fig. 8: Cylinder pressure at $3500 \mathrm{rpm}$ engine

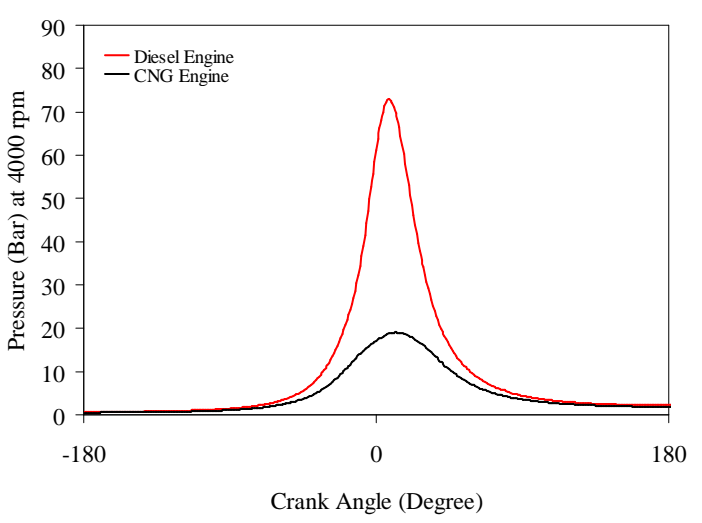

Fig. 9: Cylinder pressure at 4000 rpm engine 


\section{DISCUSSION}

The engine cylinder pressure characteristics at 1000 to $4000 \mathrm{rpm}$ of diesel engine converted to $\mathrm{CNG}$ engine have been resulted from investigations are shown in Fig. 3-9. The engine cylinder pressure profile investigation results are shown that, the cylinder pressure is increasing in compression stroke to ignition in crank angle-180 degree (BDC) until around in crank angle 0 degree (TDCF).

In the compression stroke, the air-fuel volume is compressed from BDC to TDC. The air-fuel volume is decrease and the air-fuel pressure in increase. The compression ratio of diesel engine is 20.28:1 and the compression ratio of CNG engine is 14.5:1. So, in all of engine speeds from 1000-4000 rpm are shown that the diesel engine cylinder pressure is higher than the CNG engine. The highest cylinder pressure is around in crank angle 0 degree (TDCF). Cylinder pressure is decreasing in ignition to power stroke in crank angle 0 degree (TDCF) until around in crank angle 180 degree (BDC). From this cylinder pressure performance can be predicted that the product of engine power from the airfuel combustion of diesel engine is higher than the CNG engine. The diesel engine cylinder pressure higher than $\mathrm{CNG}$ engine because the compression ratio of $\mathrm{CNG}$ engine is lower than diesel engine, where the compression ratio of compression ignition engine is 20.28:1 and compression ration of port injection $\mathrm{CNG}$ engine is reduced to $14.5: 1$. Diesel engine is a compression ignition engine, $\mathrm{CNG}$ engine is a spark ignition engine. Both of the diesel engines and CNG engine, the cylinder pressure in compression to ignition is increasing to product the engine power. The cylinder pressure in ignition to power strokes is decreasing because the pressure is changed to the engine power.

For the compression stroke to ignition of the diesel engine as shown in Fig. 3-9, the results are shown that increasing engine speed will be increase pressure maximum in-cylinder if the engine speed operated at $1000-1500 \mathrm{rpm}$ and at the over than $1500 \mathrm{rpm}$, increasing engine speed will be decrease the cylinder pressure maximum. For the compression stroke to ignition of the CNG engine as shown in Fig. 3-9, the results are shown that increasing engine speed will be decrease the cylinder pressure maximum for all of the engine speed variation cases.

The lowest maximum cylinder pressure both of diesel engine and CNG engine is shown in Fig. 3. The lowest maximum cylinder pressure in combustion process both of diesel engine and CNG engine is shown in $4000 \mathrm{rpm}$ engine speed and the nominal is $72.82 \mathrm{bar}$ for diesel engine and 17.22 bar for $\mathrm{CNG}$ engine. In this case the combustion both of diesel engine and $\mathrm{CNG}$ engine is in rapidly so the combustion process is not excellent and unburned fuel is highest, this phenomenon will be decrease the engine cylinder pressure performance.

The highest maximum cylinder pressure in combustion process of diesel engine is shown in Fig. 4 and for CNG engine is shown in Fig. 3. In the diesel engine, the nominal of maximum cylinder pressure is 84.0 bar, declared when the engine is operated in $1500 \mathrm{rpm}$ engine speed. In the $\mathrm{CNG}$ engine, the nominal of maximum cylinder pressure is 64.05 bar, declared when the engine is operated in $1000 \mathrm{rpm}$ engine speed. In this operating condition, both of diesel engine and $\mathrm{CNG}$ engine combustion process is most excellent than the other condition. In the diesel engine, the $1500 \mathrm{rpm}$ engine speed condition is not higher and not lower for the combustion of diesel engine. Burned diesel fuel rate in $1500 \mathrm{rpm}$ is most excellent and product the higher pressure and power. In the $\mathrm{CNG}$ engine, the $1000 \mathrm{rpm}$ engine speed condition is not higher and not lower for the combustion of $\mathrm{CNG}$ engine. Burned CNG fuel rate in $1000 \mathrm{rpm}$ is most excellent and product the higher pressure and power.

The maximum cylinder pressure performance effect of diesel engine converted to $\mathrm{CNG}$ engine in variation engine speed is shown in Fig. 10. At the 1000 rpm engine speed, the conversion of diesel engine to $\mathrm{CNG}$ engine is decrease the maximum cylinder pressure $22.86 \%$. At the $1500 \mathrm{rpm}$ engine speed, the conversion of diesel engine to $\mathrm{CNG}$ engine is decrease the maximum cylinder pressure $31.78 \%$. At the 2000 rpm engine speed, the conversion of diesel engine to CNG engine is decrease the maximum cylinder pressure $36.53 \%$. At the $2500 \mathrm{rpm}$ engine speed, the conversion of diesel engine to $\mathrm{CNG}$ engine is decrease the maximum cylinder pressure $47.08 \%$. At the 3000 rpm engine speed, the conversion of diesel engine to CNG engine is decrease the maximum cylinder pressure $64.51 \%$. At the $3500 \mathrm{rpm}$ engine speed, the conversion of diesel engine to $\mathrm{CNG}$ engine is decrease the maximum cylinder pressure $72.43 \%$. At the 4000 $\mathrm{rpm}$, the conversion of diesel engine to $\mathrm{CNG}$ engine is decrease the maximum cylinder pressure $76.35 \%$.

The maximum cylinder pressure for CNG engine is lower than the base diesel engine. It caused the compression ratio of $\mathrm{CNG}$ engine is lower than the base diesel engine and the combustion energy output of diesel fuel is produced highest power than the natural gas fuel. Another that, the density of gas fuel is lower than the diesel fuel. So, in the same volume, the diesel fuel is has higher pressure than the gas fuel. In this 
engine conversion, the $\mathrm{CNG}$ engine better to operate at low speed. In low speed, maximum cylinder pressure decreasing is not dramatically than at the medium and high speed. For all of engine speed, the conversion of diesel engine to $\mathrm{CNG}$ engine is decrease the cylinder pressure. It meant that the conversion of diesel engine to $\mathrm{CNG}$ engine will decrease the engine performance.

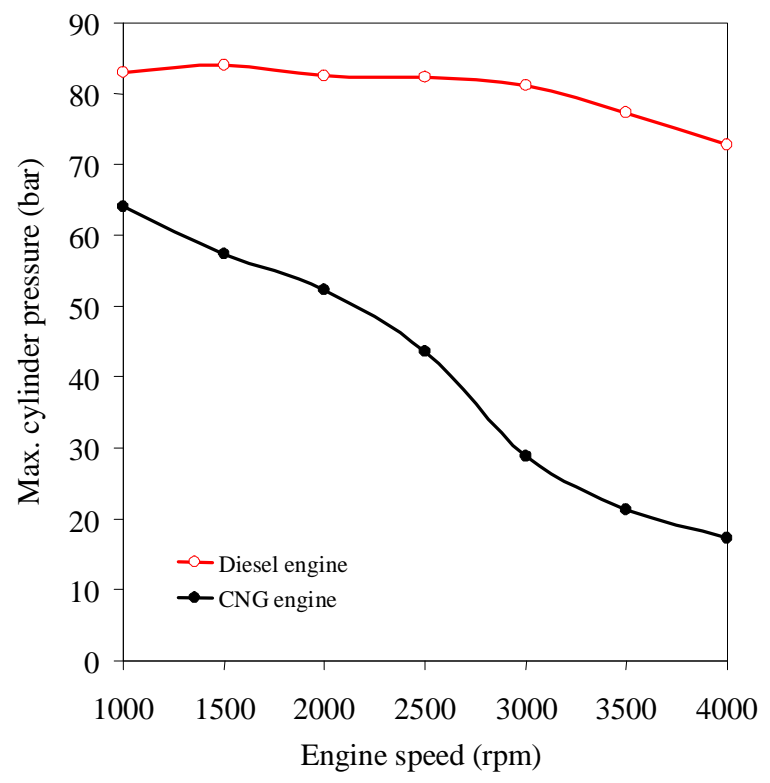

Fig. 10: Maximum cylinder pressure

\section{CONCLUSSION}

Based on the investigation results of the diesel engine convert to $\mathrm{CNG}$ engine effect on the cylinder pressure are shown that the conversion can be decrease the cylinder pressure. Both of diesel engine and $\mathrm{CNG}$ engine, the increasing engine speed will be decrease the cylinder pressure. The higher cylinder pressure is declared in low engine speed and the lower cylinder pressure is declared in high engine speed. The further research is needed to find the higher performance of CNG engine.

\section{REFERENCES}

1. Aslam, M.U., H.H. Masjuki, M.A. Kalam, H. Abdesselam, T.M.I. Mahlia and M.A. Amalina, 2006. An experimental investigation of CNG as an alternative fuel for a retrofitted gasoline vehicle. Fuel, 85: 717-724. DOI: 10.1016/j.fuel.2005.09.004
2. Bysveen Marie, 2007. Engine characteristics of emissions and performance using mixtures of natural gas and hydrogen. Energy 32: 482-489. DOI: 10.1016/j.energy.2006.07.032

3. Cho, H.M. and He Bang-Quan, 2007. Spark ignition natural gas engines-a review. Energ. Convers. Manage., 48: 608-618. DOI: 10.1016/j.enconman.2006.05.023.

4. Ganesan, V., 1999. Internal Combustion Engines. 2nd Edn., Tata McGraw-Hill, New Delhi, India, ISBN: 0070648174.

5. Heywood, J.B., 1988. Internal Combustion Engine Fundamentals. 2nd Edn., McGraw-Hill, Singapore, ISBN: 0071004998.

6. Semin, A.R. Ismail and R.A. Bakar, 2008. Comparative performance of direct injection diesel engines fueled using compressed natural gas and diesel fuel based on GT-POWER simulation. Am. J. Applied Sci., 5: 540-547. www.scipub.org/fulltext/ajas/ ajas55540-547.pdf

7. Shiga, S., S. Ozone, H.T.C. Machacon, T. Karasawa, H. Nakamura, T. Ueda, N. Jingu, Z. Huang, M. Tsue and M. Kono, 2002. A study of the combustion and emission characteristics of compressed-natural-gas direct-injection stratified combustion using a rapidcompression-machine. Combust. Flame, 129: 1-10. DOI: 10.1016/S0010-2180(01)00367-4

8. Srinivasan, K.K., 2006. The advanced injection low pilot ignited natural gas engine: A combustion analysis. J. Eng. Gas Turbines Power, 128: 213-218. DOI: $10.1115 / 1.1915428$.

9. Xu, B.Y., F.Y. Liang, S.L. Cai and Y.L. Qi, 2005. Numerical analysis of fuel injection in intake manifold and intake process of a MPI natural gas engine. Int. J. Automot. Technol., 6: 579-584. http://www.ijat.net/on_line/PaperSearch/ paper_list.asp 